\title{
SOME OBSERVATIONS ON THE INTERDISCIPLINARY \\ TEACHING OF EIGHTEENTH-CENTURY FRENCH CIVILIZATION
}

Eric A. Arnold, Jr.

Charles 0. Cook, III

University of Denver

In 1971, working with a grant of $\$ 1.25$ million from the National Endowment for the Humanities, the College of Arts and Sciences of the University of Denver initiated a new approach to the college's lower-division humanities requirement. 1 The result was the creation of several interdisciplinary block courses which involve the Departments of History, Art, Music, Theater, Religion, and Foreign Languages. The essential idea is that, by taking one of the block courses rather than a conventional quarter load of three traditionally structured courses, the student can be more effectively introduced to the various humanistic disciplines. In each block course he immerses himself in the history, literature, thought, and art of a chronologically limited but significant period in the development of a distinct national culture. In contrast to the traditional curriculum, where the student is exposed to each discipline in separate classes, this approach permits the student to see the ways in which the humanities are related, how they affect each other, and how they are affected by current political and social developments.

Since 1971, several block courses have been implemented, including Sung China, Elizabethan England, Periclean Athens, Twentieth-Century Mexico, and France of the Enlightenment and Revolution. For those of us who put the French course together, eighteenth-century France seemed an important, indeed an obvious subject, perfectly suited to the aims and methods of the block idea. The century culminating in the French Revolution and the Napoleonic Empire witnesses the birth of modern ways of thinking as well as modern social and political institutions. Such forces as Nationalism, Militarism, Political Liberalism, Socialism and Romantic Individualism first make themselves felt, for better or worse, during the period. It is a time when literature and art seem particularly sensitive to the intellectual and social changes that mark the passing of an old world and the beginning of a new vision of man.

The format of the Enlightenment and Revolution course, similar to the one used in the other block courses, consists of lectures, discussions, and workshops. In the daily lecture, usually lasting about an hour, students are exposed to the methodology of each discipline, and are introduced to the basic materials appropriate to each. Normally most lectures treat a narrowly defined subject, such as the art of Wateau, Beaumarchais' Marriage of Figaro, the conflict between Crown and Parlement, or the political thought of Rousseau. In a few necessarily broad lectures, such as "The France of Louis XIV" or "Philosophical Precursors of the Enlightenment," important background information is provided. (See Appendix A for lecture topics.)

Succeeding lectures on the political and moral environment of the Regency, the salons, the painting of Wateau and Chardin, Manon Lescaut, the Persian Letters, and Roccoco opera give the student a comprehensive idea of the Roccoco Age in France. Similarly, Rousseau's thought is considered by a literature specialist and a political philosopher, which enables the student to see the full range of impact that Rousseau had on his time. We use the same approach, with equal effectiveness, with such other men as Montesquieu, Voltaire, and Robespierre, through an examination of their work from the point of view of their various disciplines. As a result of this approach, students find that not only do ideas become easier to understand, but the men themselves seem to come alive.

Following the lecture, students and faculty hold a 45-minute discussion led by the lecturer of the day. Students are encouraged to express their 
ideas, to ask questions, to argue. After a fairly brief period at the start of the program, most of the students come to see that such activity is appropriate. Consequently, discussions are usually lively and spontaneous. The faculty are urged to attend all sessions, as their presence lends a continuity to the course, and makes it easier for them to refer back to comments made by colleagues and students in past discussions. In this way, various topics and problems are related effectively to one another, and loose ends are brought together and resolved. Students also find the conflict of opinion among faculty members to be particularly stimulating, and thus they become eager to express their own differing viewpoints. The danger to be avoided here, of course, is domination of the discussion by the faculty.

Correlative to the lectures are assigned readings. Although conventional textbooks were used (largely for the historical dimension of the program; see Appendix B for listing of texts), we make every attempt to expose the students to primary material. Thus, rather than reading about Voltaire or Montesquieu, the students read some of their representative works, in part or in entirety. Although the reading assignments are often fairly lengthy, most students are excited to read some of the actual words produced during the period, as opposed merely to reading about them. Then, too, though even a basic reading knowledge of French is not required, students who read French with any degree of proficiency or ease are most strongly encouraged to do so in conjunction with the workshops.

The third part of the course consists of a workshop which the student must select. The possibilities include History, Literature, Philosophy, and the Arts (including visual art, music, and the theater). The format of the workshops varies somewhat, but most are conducted as seminars, meeting once per week and lasting about one hour. As part of his work, each student must choose a subject and study it in depth. A typical project in history might concentrate on one man, such as Robespierre, while literature projects might offer a comparison of Diderot's Encyclopédie with the latest edition of the Encyclopedia Britannica, an investigation into pre-Romanticism, or a study of the comic effects in The Marriage of Figaro. As a result of the workshops, students write a term paper, or, as in the case of art history students, give a formal classroom presentation.

Students with nothing more than a basic competence in French are encouraged strongly to do at least some of their research in that language, and, for students in the literature workshop, if possible, to write their paper in French. One freshman, who had spent a summer in France and who had a fair degree of competence in French, translated Robespierre's speech of December, 1793, in defense of bringing Louis XVI to trial for the crime of high treason. Not only did she provide a very fine and moving translation of the speech itself, but she also delved into the published parliamentary proceedings of the subsequent trial and the current newspaper press, in order to provide background information for the presentation of the speech to the entire class. She later confided that, although the work was difficult, she had found it quite exciting to dig into the raw material of history itself. Her experience was hardly unique; other students have expressed similar reactions about their various workshop activities.

As a means of enriching the program, guest speakers have been invited to give formal lectures and to participate informally in classroom discussions. Speakers have included Arthur Wilson, Peter Gay, Henry Peyre, and Shephard Clough, who were invited specifically to present the results of their significant research. The participation of such distinguished scholars is exciting for both students and faculty; in the case of Professors Wilson and Gay, two of the greatest living authorities on the Enlightenment, the session proved 
exceptionally rich, with an informal and unplanned discussion/debate between the two men on the nature and historic significance of the Enlightenment.

Films are also shown occasionally, in order to add another dimension to the program. Among those that we have used successfully are La Prise de pouvoir de Louis XIV, A Tale of Two Cities, and La Religieuse, and the appropriate segments of Kenneth Clark's series on "Civilization." These films are shown in the afternoon. They are not meant to replace lectures but to complement them by providing students with a dramatic visual experience of the age, even if that experience is not historically objective or dispassionate as in the case of A Tale of Two Cities. During the discussion of each film, usually held after the showing, students are asked to distinguish any modern bias which may animate the dramatization. This exercise is particularly useful in that it sharpens critical awareness, and underlines differences between eighteenth and twentiethcentury points of view.

Finally, we introduced some purely "fun" projects which allow a degree of informality. For example, students were given the opportunity to have lunch at a French restaurant in Denver and to participate in French wine tasting parties. Such voluntary activities encourage a relaxed feeling, which fosters give and take in the formal academic aspects of the program. Students come to feel free to voice their opinions, to ask questions, and, in general, to become actively involved in the kind of dialogue which is such an essential part of any learning experience.

We believe that the varied approaches to teaching this course have contributed to the success of our program, as measured by student evaluations, which have consistently ranged from above average to excellent $(3.5-4.4$ on a scale of 5). Other block courses have received similar evaluations. This is not to say, however, that certain difficulties are not inherent in the implementation and conduct of block programs.

First, we have found that block courses in general, and ours in particular, do not go off as well when presented to a class that is made up largely of first-quarter freshmen. Apparently, their level of self-defined intimidation presents a formidable barrier, one that probably cannot be broken down totally; our collective solution to that problem has been a resolve not to offer the course again in the fall quarter.

Another problem concerns the workload of the faculty. In the French Enlightenment program two faculty members contribute all their teaching time during the quarter that the program is offered; they are granted full-time release from their academic departments. They present at least eight lectures apiece, conduct the bulk of the workshop projects, and handle various day-today administrative problems. Five other faculty members devote part of their' teaching time, usually one-third to one-half; they are granted partial release from their academic departments. They deliver at least five lectures, but are encouraged to be present at all classes. This, plus workshops and exams, undoubtedly constitutes a heavier workload than the conventional class. However, the excitement generated by the block courses, both for the students and the faculty, is due in part to the number of participating faculty in any one class. The faculty must be willing and able to give the necessary extra time, in order for the program to be successful.

Declining enrollments have posed the most troublesome and most perplexing problem. When they were first implemented, the block courses attracted as many as eighty students each. Since then, however, enrollments have diminished by twenty to forty students, a number which threatens the financial viability of the courses. This drop is paradoxical because, without exception, 
students have been very enthusiastic about their experience in the block courses. We cannot explain this decline with any certainty, but the most important cause may be the requirement that the student commit virtually an entire quarter's work to one course. Many students cannot accommodate a fifteen-hour block to their schedule, as in the case of Bachelor of Science majors who must take required sequence courses. Many others do not choose the block option, because they wish to take at least one other course at the same time.

Several solutions to the enrollment problem have been put into effect or are under consideration. The committee overseeing the block courses decided that beginning in the fall of 1978 , students would have the option of taking the courses for ten or fifteen credit hours. Those who opt for ten hours are excused from the workshop. Recently a committee appointed by the Dean to consider the possibility of changing the college's lower division requirements strongly recommended that all Arts and Sciences students be required to take at least one of the block courses, in the Humanities, Social, and Natural Sciences, ${ }^{2}$ as a means of fulfilling general education requirements. If both the Dean and the Faculty endorse this recommendation, the enrollment situation in all the block programs will be changed significantly. In any case, the committee's report and recommendation is clear indication of awareness by both Faculty and Administration of present difficulties facing block programs, as well as a desire to save the integrity of these programs.

Such difficulties are inherent in the concept and conduct of the block course. As a result of our own experfences, we believe that they can be outweighed by the positive features, and that the potential for learning, as well as teaching, is considerably greater than in the traditional single discipline lecture orientation.

\section{NOTES}

${ }^{1}$ See NEH grant number E045301-71-256, which 1asted from July 1, 1971, through June 30,1977 . Essentially, the money was to be used to hire new faculty that might be needed to staff any of the proposed programs.

2 For a comparative study, see J. B. Calvert, E. R. Tuttle, and P. Warren, "'The Age of Newton': An Intensive Physics and Mathematics Course," American Journal of Physics, XLIV (March, 1976), 231-235, which describes a block program in the Natural Sciences offered at the University of Denver.

\section{APPENDIX A}

\section{LECTURE TOPICS}

Lectures are grouped so that students may best see how differing modes of expression interact with one another, as the following list of lecture topics illustrates:

1. Background: France of the Late Sixteenth and Early Seventeenth Centuries.

2. France under Louis XIV.

3. The Philosophical Background of the Enlightenment.
4. Descartes' Rationalism.

5. Pierre Bayle.

6. French Operatic Music, Lully and Rameau.

7. Art, Wateau and the Aristocracy. 
8. French Classical Theater: the Tragedy.

9. Fénelon.

10. The Regency: Philippe d'Orléans and the Regency.

11. The Salons.

12. Montesquieu and Political Science.

13. Montesquieu on Liberty and Power.

14. Lesage, Turcaret.

15. Chardin and the Bourgeoisie.

16. Prévost and Manon Lescaut.

17. Marivaux and False Confessions.

18. France under Louis XV: Political and Social Conditions.

19. Leibniz.

20. Voltaire's Candide.

21. Voltaire on Man, God, and Evil.

22. Diderot and the Encyclopedie.

23. Diderot's The Nun.

24. Rousseau, Critic of Civilization.

25. Rousseau and Pre-Romanticism.
26. The France of Louis XVI, 17741787 .

27. French Keyboard Music, Lully and Rameau.

28. Beaumarchais' The Marriage of Figaro.

29. The Political and Economic Crisis of 1787-1789 and the Bastille.

30. The Political Philosophy of the Revolution.

31. Art as Propaganda.

32. David and Neo-Classicism.

33. The Marquis de Sade as Philosophe.

34. The Work of the National Assemb1y.

35. Laclos, Dangerous Connections.

36. Condorcet and the End of the Enlightenment.

37. The "Terror" and Robespierre, I.

38. The "Terror" and Robéspierre, II.

39. Thermidor and the Directory.

40. Chateaubriand.

41. Delacroix and Romanticism.

\section{APPENDIX B}

TEXTBOOKS

For the first three times that the Enlightenment and Revolution block was offered the history texts included John Lough, An Introduction to Eighteenth Century France (London, 1960); and George Rude, Revolutionary Europe, 17831815 (New York, 1964). Although Lough's work is excellent, French passages are not translated, so the change was made to Louis R. Gottschalk, The Era of the French Revolution, 1715-1815 (Boston, 1957). For the Art History dimension of the program, we have used Michael Levy, Roccoco to Revolution: Major Trends in Eighteenth Century Painting (New York, 1966).

Philosophy and literature texts included René Descartes, Discourse on Method, trans. Laurence Lafleur (New York, 1956); Jean-Jacques Rousseau, The Social Contract, trans. G.D.H. Cole (New York 1950); Crane Brinton, ed., 
The Age of Reason Reader (New York, 1956); Ben Ray Redman, ed., The Portable Voltaire (New York, 1968); Baron de Montesquieu, The Spirit of the Laws, trans. Thomas Nugent (New York, 1949); Eric Bentley, ed., The Classic Theater: Six French Plays (New York, 1961); and Denis Diderot, The Nun, trans. Leonard Tancock (London, 1974). In addition to these, the faculty distributed at various times mimeographed sheets of supplemental translated material. 